ISSN 2410-1176 (Print) Вісник КНУКіМ. Серія Мистецтвознавство. Вип. 39. ISSN 2616-4183 (Online)

УДК 7.072(477)(091)

Удріс Ірина Миколаӥвна, кандидат мистеитвознавства, Криворізький державний педагогічний університет, пр. Гагаріна,54, Кривий Ріг, Україна, 50086, https://orcid.org/0000-0002-7205-1566 sudris@ukr.net

Удріс-Бородавко Наталя Серхї̈вна, кандидат соиіологічних наук Київський національний університет культури і мистеитв, вул. С. Коновальия,36, Київ, Україна, 01133, https://orcid.org/0000-0003-1831-5476 udris.nata@ukr.net

\title{
УКРАЇНСЬКА ГРАФІКА БАРОКОВОЇ ДОБИ ЯК ПРЕДМЕТ ВИВЧЕННЯ В ПРАЦЯХ ВІТЧИЗНЯНИХ МИСТЕЦТВОЗНАВЦІВ ПЕРШОЇ ЧВЕРТІ ХХ СТОЛІТТЯ
}

Мета дослідження. Стаття присвячена вивченню процесу формування концепції національної своєрідності української графіки барокової доби в працях вітчизняних вчених київської школи першої чверті XX ст. Розглядаються наукові позиції відомих фахівців Є. Кузьміна, М. Істоміна, К. Широцького, О. Новицького, Ф. Ернста, М. Макаренка та інших авторів стосовно відмінних рис українського графічного мистецтва в контексті загальноєвропейських орієнтирів розвитку галузі та його провідної ролі в розбудові системи національної образотворчості козацької доби (XVI-XVIII ст.). Простежується внесок учених часів становлення науки про мистецтво в дослідження еволюції художнього оздоблення вітчизняних стародруків, тез та інших графічних творів у контексті стильових тенденцій тієї епохи. Методи дослідження полягають у комплексному історико-культурному підході, системному методі, синхроністичному аналізі публікацій одного часового проміжку, структурному аналізі. Наукова новизна. На основі аналізу наукових досліджень у цій статті систематизовано фрагменти досліджень українських мистецтвознавців першої чверті XX ст. щодо особливостей графіки «козацької» доби. Доведено, що у козацькі часи сформувалась самостійна національна мистецька школа, а майстри прагнули відтворити місцеву візуальну систему - типажі людей, одяг, побут, природне довкілля тощо. У графічних композиціях застосовувалась численна символіка саме місцевого характеру. Для вивчення особливостей графіки та перенесення іï в сучасний графічний дизайн необхідно аналізувати стародруки, які зберігаються в бібліотеках та музеях України, робити копії та розробляти варіанти імплікацій. Виявлено, що серед вагомих композиційних особливостей як вияву самостійності українських графіків є застосування аркової схеми - орнаментовані пишними рослинними елементами та рамки $з$ текстом або основним сюжетом у центрі. Висновки. Розглянутий матеріал засвідчує беззаперечну значимість й національну неповторність української графіки означеного періоду; зорієнтовує сучасних графічних дизайнерів на пошуки прийомів національної ідентичності дизайн-проектів та надає для цього підгрунтя.

Ключові слова: українська графіка; національні форми; мистецтвознавство; українське барокко; гравюра.

Удрис Ирина Николаевна, кандидат искусствоведения, Криворожский государственный педагогический университет, пр. Гагарина, 54, Кривой Рог, Украина

Удрис-Бородавко Наталья Сергеевна, кандидат сочиологических наук, Киевский национальный университет культуры и искусств, ул. Е. Коновальца, 36, Киев, Украина

Украинская графика барочной эпохи как предмет изучения в трудах отечественных искусствоведов первой четверти XX века 
Цель исследования. Статья посвящена изучению процесса формирования концепции национального своеобразия украинской графики барочной эпохи в трудах отечественных ученых киевской школы первой четверти XX в. Рассматриваются научные позиции известных специалистов - Е. Кузьмина, М. Истомина, К. Широцкого, О. Новицкого, Ф. Эрнста, М. Макаренко и других авторов об отличительных особенностях украинского графического искусства в контексте общеевропейских ориентиров развития отрасли и его ведущей роли в развитии системы национального изобразительного искусства казачества (XVI-XVIII вв.). Прослеживается вклад ученых времен становления науки об искусстве в исследование эволюции художественного оформления отечественных старопечатных книг, тезисов и других графических произведений в контексте стилевых тенденций той эпохи. Методы исследования заключаются в комплексном историко-культурном подходе, системном методе, синхронистичном анализе публикаций одного временного промежутка, структурном анализе. Научная новизна. На основе анализа научных исследований в этой статье систематизированы фрагменты исследований украинских искусствоведов первой четверти XX в. об особенностях графики «казацкого» времени. Доказано, что в казацкие времена сформировалась самостоятельная национальная художественная школа, а мастера стремились воссоздать местную визуальную систему - типажи людей, одежда, быт, окружающую среду и тому подобное. В графических композициях применялась многочисленная символика именно местного характера. Для изучения особенностей графики и переноса ее в современный графический дизайн необходимо анализировать старопечатные книги, которые хранятся в библиотеках и музеях Украины, делать копии и разрабатывать варианты импликаций. Выявлено, что среди весомых композиционных особенностей как проявления самостоятельности Украинской графики применение арочной схемы орнаментированные пышными растительными элементами и рамки с текстом или основным сюжетом в центре. Результаты и выводы. Рассмотренный материал свидетельствует о значимости и национальной неповторимостиь украинской графики определенного периода; ориентирует современных графических дизайнеров на поиски приемов национальной идентичности дизайн-проектов и предоставляет для этого основания.

Ключевые слова: Украинская графика; национальные формы; искусствоведение; украинское барокко; гравюра.

Udris Irina, PhD in Art Criticism, Kryvyi Rih State Pedagogical University, 54, Haharina Avenue, Kryvyi Rih, Ukraine

Udris-Borodavko Nataliia, PhD in Sociological Sciences, Kyiv National University of Culture and Art, 36, Y. Konovaltsia St., Kyiv, Ukraine

\section{Ukrainian graphics of the Baroque Era as a subject study in the domestic art critics' works (the first quarter of the $\mathrm{XX}$ century)}

Main objective of the study. The article is devoted to the study of the process of national originality concept formation of the Baroque age Ukrainian graphic arts in the writings of the Kyiv school scientists of the first quarter of the twentieth century. The scientific positions of such wellknown experts as E. Kuzmin, M. Istomin, K. Shirotsky, O. Novitsky, F. Ernst, M. Makarenko and other authors concerning distinctive features of the Ukrainian graphic art in the context of the allEuropean guidelines for the branch development, as well as its leading role in the Cossack age (XVI-XVIII centuries) national art system development. The articles researches the scholars' contribution to the science of art formation, in particular, the evolution of the artistic decoration of domestic early-print, thesis, and other graphic works in the context of that era style trends. Methodology consist of a complex historical-cultural approach, a systematic method, a synchronic analysis of publications of the same time interval, structural analysis. Scientific novelty. On the basis of scientific researches analysis the article systematizes the fragments of the Ukrainian art historians researches of the first quarter of the XXth century concerning the of the "Cossack" era graphic features. It has been proved that during the Cossack times there was formed an independent national art school, and the masters sought to recreate the local visual system - the types of people, 
clothing, life, natural environment, etc. The graphic compositions used a lot of the local symbolics. To study the features of graphics and move it into modern graphic design, it is necessary to analyse the old printed books, stored in libraries and museums of Ukraine, make copies and develop variants of implications. It is revealed that among the valid compositional features as the manifestation of the Ukrainian graphists' independence, there is an arch type sample, ornamented with lush vegetative elements and framed with a text or a main story in the centre. Results and conclusions. The considered material confirms the unquestionable significance and national uniqueness of the Ukrainian graphics of the studied period; it stipulates contemporary graphic designers to search for the national identity design projects techniques and providing them with the basis for this.

Key words: Ukrainian graphic arts; national forms; art studies; Ukrainian baroque; engraving.

Вступ. Сучасний стан розвитку нашого суспільства обумовлює посилення інтересу до власної культурної спадщини, усвідомлення необхідності ії вивчення з метою підтримки безперервності української традиції та пошуку шляхів подальшого поступу в образотворчому мистецтві та дизайні. Для розвитку сучасного графічного дизайну фундаментальним $є$ дослідження української графіки, особливо тих іï періодів, коли самобутні національні риси виявлялися якнайбільше. До таких періодів належить так звана «барокова» або «козацька» доба. При цьому вельми важливим знанням $\epsilon$ таке, що отримано при вивченні численної кількості автентичних оригіналів, які збереглися 3 тих часів. Формування концепції національної образотворчості на основі аналізу творів українських художників бере початок у грунтовних дослідженнях українських мистецтвознавців останньої чверті XIX та перших десятиліть XX ст. Емпірична база їхніх досліджень кількісно набагато більша та цінніша, ніж наших сучасників, оскільки протягом XX ст. українська мистецька спадщина минулих часів зазнала численних пошкоджень та знищень. А отже висновки - більш грунтовні та об'єктивні. Саме тому необхідним $\epsilon$ вивчення мистецтвознавчих досліджень українських науковців межі XIX та XX ст.

Аналіз останніх досліджень і публікацій. Вивченням спадщини науковців останньої чверті XIX та перших десятиліттях XX ст. сьогодні займаються В. Ульяновський, О. Франко, О. Сторчай, Т. Стефанишин, С. Міщук, О. Мандебура-Нога та ін. Вагомим внеском у вітчизняну історію науки про мистецтво стала праця О. Ноги «Проект пам'ятника Івану Левинському» (1997), де зокрема проаналізовано внесок тогочасних вітчизняних науковців у формування уявлень про український національний стиль у різних видах образотворчості. У книзі С. Побожія «3 історії українського мистецтвознавства» (2005) розглянута наукова спадщина представників харківської школи мистецтвознавства часів становлення. Помітним явищем у справі дослідження витоків формування вітчизняного мистецтвознавства варто вважати фундаментальну тритомну працю М. Палієнко (2005), присвячену журналу «Кіевская старина». Низка вагомих аспектів процесу становлення вітчизняного наукового мистецтвознавства висвітлюється в публікаціях М. Криволапова (2004). Творча спадщина В. Щербаківського характеризується в грунтовній публікації В. Ульяновського (1995). У біобіліографічних нарисах С. Шудрі «Дослідники народного мистецтва» (2008) зібрано й систематизовано бібліографію праць таких науковців окресленої доби - Г. Павлуцького, М. Біляшівського, С. Кузміна, М. Сумцова, К. Широцького та багатьох інших. Різні аспекти дослідницької діяльності науковців Полтавщини початку ХХ ст. висвітлені в численних публікаціях В. Ханка (2007). У названих працях частково характеризуються наукові погляди дослідників початку століття стосовно досягнень української графіки барокової доби як золотого віку вітчизняного образотворчого мистецтва. Однак цілісне наукове дослідження, в якому сконцентровано думки мистецтвознавців зазначеного періоду лише стосовно графіки барокової доби та зроблено висновки щодо даної проблеми - відсутнє. Це доводить актуальність та наукову новизну цієї статті. 
Метою статті $є$ дослідження процесу формування концепції національних форм української графіки козацьких часів та іiі ролі в загальному розвитку образотворчості барокової доби в працях вчених київської школи першої чверті XX ст.

Виклад основного матеріалу дослідження. На початок XX ст. рівень дослідження української образотворчої класики по різним видам мистецтва був неоднаковим. Найбільше публікацій було присвячено архітектурі та народному мистецтву і проведена науковцями робота стала підгрунтям визначення національних форм в обох галузях. Вагомі успіхи були досягнуті в сфері дослідження живопису. Менше уваги приділялось вивченню графіки. Вітчизняні науковці в ті роки побіжно розробляли даний вид мистецтва. Так, в повідомленні Степана Голубєва «О начале книгопечатания в Києве», подано огляд нечисленної літератури щодо початку діяльності друкарні в Києво-Печерській лаврі (1890). У статті Василя Горленка «Старинная южнорусская гравюра» міститься стислий огляд діяльності київської й чернігівської друкарень, а також творчості найвідоміших майстрів (1890). Варто згадати й описи Пересопницького рукопису Павла Житецького (1876) та Миколи Думитрашка (1874).

Ситуація повільно змінюється протягом 1900-х рр., коли активізується вивчення національної своєрідності в різних галузях образотворчості. У статті Євгена Кузьміна про південно-руське мистецтво та необхідність його дослідження окреслено широке коло завдань у даному напрямку (1900). Формулюючи тезу про особливу роль України як пограниччя двох культур, вчений намічає низку точок відліку для подальших досліджень, констатуючи формування в козацькі часи самостійної національної мистецької школи (Кузьмін, 1900, с. 327). Є. Кузьмін високо оцінює твори графіки тієї доби. Особливо приваблює автора прагнення майстрів «передать своё, родное - местные типы, местную обстановку» (Кузьмін, 1900, с. 329).

Згадуючи ілюстрації Печерського патерика, він акцентує увагу на пейзажах Дніпра, характерному одязі козацької старшини окремих персонажів тощо. Ту ж своєрідність вбачає вчений і в орнаментації вітчизняної книги. Позбавлені витонченості західних аналогів, наші орнаменти демонструють, на його думку, приховану твердість сучасників Хмеля і Петра Могили. Є. Кузьмін зазначав, що захід давав у справі візуалізації лише зразки, за якими українські графіки вчились творити самостійно (1900, с. 329).

Михайло Істомін у контексті проголошеної теми значну увагу приділяє розвитку графічного мистецтва в статті, що переважно присвячена вивченню живопису в КиєвоПечерській лаврі в XVIII ст. (1901). По суті, предметом аналізу стали стародруки, альбоми і зошити лаврської бібліотеки: лицьові Біблії переважно німецького видання; навчальні посібники 3 малювання - славнозвісні «кужбушки»; навчальні малюнки. У роботі висловлюється припущення, що намісник Лаври Антоній Тарасевич - в миру Олександр - i гравер Леонтій Тарасевич - одна особа (Истомин, 1901, с. 295). Таким чином, на думку вченого, пояснюється той факт, що висока духовна особа була власником солідної збірки художніх видань, а значна частина робіт Л. Тарасевича пов'язана 3 монастирем. Характеризуючи улюблені лаврськими майстрами сюжети, автор доходить висновку, що українська гравюра XVII - XVIII ст. помітно впливала на еволюцію вітчизняного іконопису.

Єгор Рєдін в публікації, присвяченій церквам Харкова, описуючи предмети церковного ритуалу харківських храмів, кількома рядками засвідчує наявність Євангелій київського та львівського друку (1905). Детальніше він зупиняється на характеристиці вихідного аркуша Євангелія 1707 р., зазначаючи що уміщені символічні зображення $\epsilon$ характерними для цього виду нашого мистецтва означених часів (Редин, 1905, с. 31). Опис вдало фіксує особливості образної мови української барокової гравюри.

Вивчення вітчизняної графіки козацької доби активізується в 1910-ті р. Микола Петров у 1914 р. оприлюднює розвідку про гравірувальні дошки Києво-Печерської, Ільїнської, Чернігівської та Почаївської друкарень, де розглянуто поширення популярних сюжетів та варіанти їх трактування. С. Кузьмін, продовжуючи принципи аналізу на основі аналогій, в нарисі про український живопис XVII ст. звертається й до графічних творів. В оцінках стану мистецтва на початку доби він опирається переважно на видання КиєвоПечерської лаври (Кузьмин, 1910-1915, с. 455-457). Серед творів початку століття автор 
виділяє портрет гетьмана Сагайдачного 1622 р. Стосовно графіки кінця XVII - початку XVIII ст. в роботі лаконічно відмічається висока якість гравюр київських видань, що пов'язується 3 посиланням на працю М. Істоміна - 3 діяльністю Л. Тарасевича. С. Кузьмін відмічає також роботи майстра Федора, зокрема Свангеліє 1697 р. (1910-1915, с. 471).

У 1914 р. 3'являється й огляд національної гравюри Миколи Макаренка. В його основі - теза про необхідність вивчення графіки XVII ст. як провідної галузі образотворчості доби з метою глибшого проникнення в інші ділянки художньої діяльності (Макаренко, 1914, c. 198). Авторська позиція відносно методологічних засад вивчення мистецьких творів виявляється в словах: «Изучать же произведения вне связи их с политической и культурной жизнью края едва ли мыслимо» (Макаренко, 1914, с. 200). Вченого вражає швидкий процес кристалізації національних рис у графіці на основі освоєння західних зразків. Розквіт техніки та художніх якостей книжкової гравюри в XVII ст. він пояснює загальним розвитком естетичних потреб українського суспільства, відмічаючи «в высшей степени культурное отношение к книге со стороны читателя» (Макаренко, 1914, с. 199). Загальна характеристика особливостей вітчизняної гравюри доповнюється детальнішим аналізом дереворитів Євангелія Учительного 1637 р., в яких на думку автора західноєвропейські мотиви вже отримали цілком своєрідне тлумачення.

У тому ж номері часопису «Искусство в Южной России» опубліковано статтю Костянтина Широцького про життя й діяльність Г. Левицького (під криптонімом К. Ладиженко) (Ладыженко, 1914). Підгрунтям формування творчої особистості митця автор вважає навчання в Київській Академії, де до змісту освіти входило викладання цивільної архітектури та рисування, відбувались диспути з тезами, театральні вистави, інші академічні заходи (Ладыженко, 1914, с. 176). Підкреслюється роль посади «справщика» КиєвоПечерської друкарні, яку обіймав Г. Левицький майже до смерті, у загальному розвитку книжкової продукції, відмінними рисами котрої називаються одухотвореність, відображення характерів, смаків і звичаїв українського суспільства (Ладыженко, 1914, с. 178).

Вихідна концепція К. Широцького позначається на аналізі конкретних робіт. Автор позитивно оцінює ранні ілюстрації Г. Левицького до «Апостола» і «Свангелія», виданих у 1737 р. Особливо відмічаються аркуші «Взяття на небо Богородиці» та «Отроки Ісус та Іоанн», де вже простежується схильність до алегорій, що блискуче реалізується в таких творах як тези на честь I. Негребецького та Р. Заборовського. Детально описується в статті зміст цих грандіозних гравюр і значення символів, що характеризують місце й діяльність осіб, яким твори присвячені (види Лаври і Михайлівського монастиря, Академічний корпус, зображення спудеїв) (Ладыженко, 1914, с. 185). Аналіз образів I. Негребецького та Р. Заборовського в тезах дає підстави вченому відмітити талант Левицького-портретиста (Ладыженко, 1914, с. 188). До розряду портретів відносить автор і зображення Дмитра Ростовського 1752 р. Схвальну оцінку отримують ілюстрації до «Політики» Аристотеля, присвяченої О. Розумовському. У підсумку зазначено, що Г. Левицький - видатний майстер, творчість якого завершує діяльність таких поколінь українських граверів, що вплинули на розвиток мистецтва всієї імперії.

Певні міркування щодо графіки барокової доби як елементу житлового інтер'єру містяться в праці вченого, присвяченій живописному оздобленню української хати в минулому й сучасності (Широцкий, 1914). Роль стародруків у житті українського суспільства козацької доби К. Широцький розглядає і в статті «Церковні стародруки» (Широцький, 1918). Предметом зацікавлення в ній стає розповсюдження видань друкарень Києва, Львова, Почаєва серед різних верств українського населення. Вченого захоплює висока якість продукції Києво-Печерської та Ставропігійської львівської друкарень, які постачали книжки не лише у всі міста України, а й в інші країни (Широцький, 1918, с. 810). На основі записів власників на сторінках книг автор виявляє як i за яку ціну купувались стародруки, передавались у спадщину, віддавались у заставу, дарувались братствам і церквам. Наведені факти підтверджують роль церковної книги, яка задовольняла духовні, розумові та естетичні потреби багатьох поколінь українців (Широцький, 1918, с. 812-813). 
Федір Ернст віддає належне вітчизняному мистецтву гравюри в праці «Українське мистецтво XVII-XVIII віків» (1919). Становлення галузі в Україні в XVI ст. автор розглядає в тісному зв'язку з книгописанням, коли більшість майстрів опираються на зразки не лише 3 німецьких чи польських видань, а й зі старих вітчизняних рукописів (Ернст, 1919, с. 10). Характеризуючи досягнення української графіки XVII ст., Ф. Ернст відмічає формування локальних шкіл у друкарських осередках і поділяє думки інших дослідників відносно того, що орієнтація на західне друкарство не перешкоджає нашим митцям формувати власне, оригінальне мистецтво (1919, с. 16). Наші видання містять часто композиції цивільного змісту i, високо цінуючи їх, автор наводить у приклад видання київської друкарні: Патерики, де можна зустріти світські сцени національного трактування, аркуш «Вірш на погреб гетьмана Сагайдачного» 1622 р. тощо.

Мазепинські часи визначаються в дослідженні як розквіт усіх видів національної образотворчості й особливо - графіки, де спостерігається перехід на мідьорити. Ф. Ернст вважає Л. Тарасевича кращим гравером мазепинської доби, порівнюючи ілюстрації до Печерського Патерика 1702 р. 3 визнаними творами тогочасної європейської гравюри (1919, c. 20). До видатних досягнень національної образотворчості належать роботи І. Щирського, I. Мигури. У середині XVIII ст. в західних областях України, за словами вченого, у книжковій графіці нівелюється національна специфіка, а в центральних регіонах гравюра відходить на другий план порівняно з малярством. Щодо творчості Г. Левицького, Ф. Ернст слушно підмічає, що порівняно з попереднім періодом його твори мають інший характер, «більш тонкий, легкий, граціозний», притаманний рококо (1919, с. 26).

Висвітлення барокової графіки в публікаціях початку 1920-х рр. сприймається як узагальнення наукових поглядів доби. Історик церкви Федір Титов дослідив розвиток вітчизняної гравюри 3 архівно-історичної точки зору (1924). Символіку в українській образотворчості середньовіччя й козацьких часів в статті «Символічні образи на ритинах київських стародруків» проаналізував Олексій Новицький (1926). Обгрунтовуючи звернення до зазначеної теми, він стверджує, що в Україні символіка захоплювала всі види мистецтва i, отже, була його найхарактернішою рисою. Аналіз автор починає з Розп'яття, яке набуває у низці стародруків символічного трактування, як наприклад, в «Евхологіоні» 1646 р., де 3 дерева хреста проростають галузки 3 квітами-медальйонами, в яких зображені таїнства православної церкви (Петров, 1914, с. 143). Серед символів Розп'яття розглядаються мідний змій, знаряддя мук Христа, рука з грішми як емблема зради Іуди, півень як символ зречення Петра, дві руки над чашею як символ вмивання рук Пілатом тощо. Значну увагу приділено тлумаченню образів пелікана, оленя, василіска, фенікса.

Наступна група символів, розглянутих у статті, пов'язана з темою Богородиці. Серед них О. Новицький виділяє композицію у «Толковій Псалтирі» 1697 р., де зображення Богородиці з Христом на руках наближається за типом до «Неопалимої купини» (1926, c. 148). Одним з важливих образів у цих сценах він вважає Велику Лаврську церкву, яка тут символізує Божу Матір і взагалі неодноразово зустрічається в стародруках в якості символу. Характерним символом Богородиці виступає образ єдинорога, що до нас прийшов із середньовічного Заходу. Розглядається група символів, пов'язаних з євангелістами, а також улюблена в Україні, на думку автора, тема «Дерева Євсеєва» (Новицький, 1926, с. 150).

В огляді оформлення теологічної літератури і тез вчений опирається на аналіз творів Лазаря Барановича «Меч духовний» 1666 р. та «Труби словес проповідних» 1674 р. (Новицький, 1926, с. 152). Дослідник простежує значення кожного елементу композицій титулів, зіставляючи їх з відповідними текстами. Так, виявлено, що на титулі видання «Меч духовний» в одному аркуші згуртовано символіку, яка опирається на Апокаліпсис, Євангеліє, Псалтир, інші книги Нового завіту і на міркування самого Л. Барановича. Той же принцип покладено в основу рішення титулу другого видання. (Новицький, 1926, с. 154). У підсумку підкреслюється, що в Україні козацької доби любили i широко вживали різноманітну символіку і поряд з мотивами, що прийшли з інших культур, використовували 
місцеві мотиви. Оскільки на час написання статті значна кількість символів втратила свою ясність, публікація відіграла важливу роль для вивчення проблеми.

М. Макаренко в праці «Орнаментація української книжки XVI-XVII ст.» поєднав детальне коментування окремих компонентів оздоблення книги 3 досить широкими узагальненнями (1926). Автор пов'язує найвищий розквіт вітчизняної книжкової справи 3 суспільно-культурним поступом, який переживала країна у визначену добу і ставить занепад книгодрукування у XVIII ст. в залежність від натиску з боку московської влади. Виклад матеріалу він формує за структурною схемою книжкового оформлення.

Грунтовно досліджується в роботі художнє оздоблення вихідного аркуша, «по якому зустрічає книжку читач» (Макаренко, 1926, с. 6). Точкою відліку є теза про те, що в найдавніших стародруках оформлення вихідного аркушу найповніше відповідає текстові, а ближче до XVIII ст. ця відповідність нівелюється (Макаренко, 1926, с. 8). Базову композиційну схему - орнаментовану арку з текстом всередині - М. Макаренко виводить 3 перших «Апостолів» I. Федорова та інших майстрів й традиційних зображень євангелістів (1926, с. 10). Композиції цілком орнаментальних рамок, лише в загальних обрисах підпорядкованих арковій схемі («Євангеліє Учительне» 1637 р. лаврського друку), вчений вважає виявом самостійності українських митців. Захоплення ж у XVIII ст. чистими архітектурними формами характеризується як втрата цілісності графічного оформлення аркуша (Макаренко, 1926, с. 15).

Майстерно проведено порівняльний аналіз архітектурних обрамлень аркушів львівського «Апостола» 1574 p. 3 московським «Апостолом» 1564 р., віленським «Апостолом» 1594 р. і Острозькою Біблією 1581. М. Макаренко зіставляє зображення, фіксує різницю в деталях, техніці виконання і обстоює «окреме» походження кожного кліше (Макаренко, 1926, с. 19-22). 3 часом аркове обрамлення, наголошує вчений, набуває більшої декоративності на взірець вихідного аркуша «Часослова» 1625 р., що продиктовано бажанням дати «як-найкращу окрасу» і чіткіший заголовок книжці (Макаренко, 1926, с. 24). Зростаюче тяжіння до пишного оздоблення вихідних аркушів пояснюється змінами в смаках населення (Макаренко, 1926, с. 31). Зразками збагачення базової композиційної схеми називаються «Літургіаріон» 1708 р. та «Камінь віри» 1730 р.

Ще виразніше виявлені особливості простежуються в оздобленні книг більш світського призначення, де митці розгортають світ «фантастики, зачарованості, неземної краси та чудових уявлень», який відображає «веселу і гучну епоху XVIII ст.» (Макаренко, 1926, с. 35). Окрему увагу приділяє вчений звичаєві уміщувати на звороті титулу герб особи, що сприяла виданню, особливо - в панегіричній літературі. Розглядаючи герби представників польської шляхти й української старшини, М. Макаренко підкреслює, що провідна роль гербів у книжці - декоративна і одним 3 кращих взірців української гравюри вважає герб I. Мазепи у «Зерцалі од писанія Божественного» 1705 р. (Макаренко, 1926, с. 43). Вихідною тезою розділу про книжкові заставки також є утвердження їхньої декоративної функції (Макаренко, 1926, с. 44). На численних прикладах вибудовується схема еволюції від композицій 3 пишними рослинними мотивами через ускладнене орнаментування 3 включенням сюжетних картушів і до майже панівної ролі сюжетних заставок, де орнамент лише облямовує основну сцену.

В аналізі кінцівок відмічається інша концепція оздоблення: у кінцівках часто зустрічаються геометричні орнаменти і в них більше запозичень з німецьких, італійських та інших видань. Автор звертає увагу на рішення заголовних літер та облямування сторінок 3 текстом делікатними рамками. Він зупиняється і на похибках у стародруках, серед яких часто зустрічається перевернуте кліше з інших видань (Макаренко, 1926, с. 62). У загальних висновках висловлюється переконання, що українська книга немає повних аналогій в оздобленні як з виданнями, друкованими кирилицею, так і з книгами, писаними латиною, виданими у європейських типографських осередках (Макаренко, 1926, с.68). Загалом праця М. Макаренка блискуче підсумовує доробок української науки про мистецтво періоду становлення у вивченні графіки козацьких часів. 
Наукова новизна. У статті систематизовано фрагменти досліджень українських мистецтвознавців першої чверті XX ст. щодо особливостей графіки «козацької» доби. Доведено, що у козацькі часи сформувалась самостійна національна мистецька школа, а майстри прагнули відтворити місцеву візуальну систему - типажі людей, одяг, побут, природне довкілля тощо. У графічних композиціях застосовувалася численна символіка саме місцевого характеру. Виявлено, що серед вагомих композиційних особливостей як вияву самостійності українських графіків $є$ застосування аркової схеми - орнаментовані пишними рослинними елементами та рамки з текстом або основним сюжетом у центрі. Ми вважаємо, що для вивчення особливостей графіки та перенесення iї у сучасний графічний дизайн необхідно аналізувати стародруки, які зберігаються в бібліотеках та музеях України, робити копії та розробляти варіанти імплікацій.

Висновки. Розглянутий матеріал засвідчує, що українська графіка - зокрема, друкована книга - як предмет наукового дослідження привертає увагу фахівців часів становлення мистецтвознавства дещо пізніше, ніж інші види образотворчості, однак ця ділянка художньої діяльності apriori сприймалась як високохудожня і відповідно трактувалась. Науковці зверталися і до аналізу одиничних пам'яток української барокової графіки, і до узагальненої характеристики здобутків у галузі, визначаючи характерні риси, художні якості українського графічного мистецтва. В своїх оцінках вчені дотримувалися однакової загальної концепції про національну самобутність нашої графіки і вважають козацьку добу періодом її найвищого розквіту, коли цей вид образотворчості був провідним і впливав на інші галузі та національні школи.

Таким чином, праці фахівців першої чверті XX ст. й донині не лише не втрачають актуальності й наукової цінності і для фахівців-практиків, теоретиків історії мистецтва та мистецтвознавства, але й надають вагому узагальнену інформацію для опрацювання нових візуальних систем, зокрема в графічному дизайні.

\section{Список використаних джерел}

1. Голубев С. О начале книгопечатания в Києве. Киевская старина. Киев, 1890. №1. С. 381-384.

2. Горленко В. Старинная южнорусская гравюра. Киевская старина. Киев, 1890. №1. С. 47-50.

3. Думитрашко Н. Замечательная рукопись Полтавской семинарии - Пересопниикое евангелие. Полтава, 1874. 29 с.

4. Ернст Ф. Украӥнське мистецтвво XVII - XVIII віків. Київ : Криниця, 1919. 32 с.

5. Житецкий П. Описание Пересопницкой рукописи XVI в. с приложением текста Евангелия от Луки, выдержек из других евангелистов и 4-х странии снимков. Київ, 1876. 79 с.

6. Истомин М. Обучение живописи в Киево-Печерской Лавре. Искусство $u$ художественная промышленность. 1901. № 9/10. С.293-310.

7. Криволапов М. Мистецтво та соціально-культурні процеси в Україні на початку XX століття. Мистецтввознавство України. Вип. 4. Київ, 2004. С.6-25.

8. Кузьмин Е. Несколько слов о южно-русском искусстве и задачах его исследования. Киевская старина. 1900. № 11. С. 327-332.

9. Кузьмин Е. Украинская живопись XVII столетия. История русского искусства / под ред. И. Грабаря. Москва, 1910-1915. Т.6. С. 455-482.

10. Ладыженко К. (Широцький К.) Жизнь и деятельность Григория Кирилловича Левицкого. Искусство в Южной России. 1914. № 5-6. С. 175-189.

11. Макаренко Н. Материалы по истории гравюры на Украине. Искусство в Южной России. Живопись, графика, художественная печать. 1914. №5/6. С.190-202.

12. Макаренко М. Орнаментація української книжки XVI - XVIII ст. Труди Украйнського наукового інституту книгознавства. Київ, 1926. Т.1. С.1-70.

13. Новицький О. Символічні образи на ритинах київських стародруків. Записки HTU. T.CXLIV. 1926. C.141-158.

14. Нога О. Проект пам'ятника Івану Левинському. Львів : Українські технології, 1997. $327 \mathrm{c}$. 
ISSN 2410-1176 (Print) Вісник КНУКіМ. Серія Мистецтвознавство. Вип. 39. ISSN 2616-4183 (Online)

15. Палієнко М. «Кіевская старина» (1882-1906). Систематичний покажчик змісту журналу. Київ : Темпора, 2005. 608 с.

16. Паліснко М. «Кіевская старина» (1882-1906). Хронологічний покажчик змісту журналу. Київ : Темпора, 2005. 480 с.

17. Палієнко М. «Кіевская старина» у громадському та науковому житті України (Кінець XIX-початок XX cm.). Київ : Темпора, 2005. 384c.

18. Петров Н. Южно-русские гравировальные доски типографий Киево-Печерской, Ильинской, Черниговской и Почаевской. Искусство в Южной России. 1914. №3-4. С.89-96.

19. Побожій С. 3 історії українського мистеитвознавства. Суми : ВТД «Університетська книга», 2005. 184 с.

20. Редин Е. Материальы к изучению иерковных древностей Украины:: Церкви города Харькова. Харьков : «Печатное дело» кн. К. Гагарина, 1905. 64 с.

21. Тітов Хв. Матеріали до історії книжкової справи на Украӥні в XVI-XVIII вв. Київ : 3 друк. Укр. акад. наук, 1924. 546 с.

22. Ульяновський В. Вадим Щербаківський: життя, наукова діяльність, доля творчої спадщини. Київ : Либідь, 1995. 288 с.

23. Ханко В. Мистецтвознавча думка на Полтавщині. Полтава : Полтава, 2007. 134 с.

24. Широцкий К. Очерки по истории декоративного искусства Украины. Т.1. Художественное убранство украинского дома. Київ : тип. С. Кульженко, 1914. 153 с.

25. Широцький К. Церковні стародруки. Книгар. Літопис украӥнського письменства. Київ, 1918. Ч.14. С.809-814.

26. Шудря С. Дослідники українського мистецтва. Біобібліографічні нариси. Зошит 3. / за ред. д-ра мистецтвознавства М. Селівачова. Київ : Вісник «АНТ», 2008. 116 с.

\section{References}

1. Golubev, S. (1890). O nachale knigopechataniya v Kieve [About the beginning of printing in Kiev]. Kievskaya starina, no. 1, pp. 381-384

2. Gorlenko, V. (1890). Starinnaya yuzhnorusskaya gravyura [Old South Russian engraving]. Kievskaya starina, no. 1, pp. 47-50.

3. Dumitrashko, N. (1874). Zamechatel'naya rukopis' Poltavskoi seminarii-Peresopnitskoe evangelie [Wonderful manuscript of the Poltava seminary - Peresopnytsia gospel]. Poltava.

4. Ernst, F. (1919). Ukrainske mystetstvo XVII-XVIII vikiv [Ukrainian art of the XVII-XVIII centuries]. Kyiv : Krynicya.

5. Zhitetskii, P. (1876). Opisanie Peresopnitskoi rukopisi XVI v. s prilozheniem teksta Evangeliya ot Luki, vyderzhek iz drugikh evangelistov $i 4$ stranits snimkov [Description of the Peresopnitsa manuscript of the XVIth century with the appendix of the text of the Gospel of Luke, excerpts from other evangelists and 4 pages of pictures]. Kyiv.

6. Istomin, M. (1901). Obuchenie zhivopisi v Kievo-Pecherskoi Lavre [Teaching painting in Kiev-Pechersk Lavra]. Art and art industry, no. 9-10, pp. 293-310.

7. Kryvolapov, M. (2004). Mystetstvo ta sotsialno-kulturni protsesy v Ukraini na pochatku $\mathrm{XX}$ st. [Art and socio-cultural processes in Ukraine at the beginning of the twentieth century]. Art studies of Ukraine, no. 4, pp. 6-25.

8. Kuz'min, E. (1900). Neskol'ko slov o yuzhno-russkom iskusstve i zadachakh ego issledovaniya [A few words about South Russian art and the objectives of its research]. Kievskaya starina, no. 4, pp. 6-25.

9. Kuz'min, E. (1910-1915). Ukrainskaya zhivopis' XVII st. [Ukrainian painting of the XVII century]. History of Russian Art, Vol. 6, pp. 455-482.

10. Ladyzhenko, K. (Shirots'kii K.) (1914). Zhizn' i deyatel'nost' Grigoriya Kirillovicha Levitskogo' [The life and work of Gregory Kirillovich Levitsky]. Art in Southern Russia, no. 5-6, pp. 175-189.

11. Makarenko N. (1914). Materialy po istorii gravyury na Ukraine [Materials on the history of engraving in Ukraine]. Art in Southern Russia. Painting, graphics, art print, no. 5-6, pp. 190-202. 
12. Makarenko M. (1926). Ornamentatsiia ukrainskoi knyzhky XVI - XVIII st. [Ornamentation of the Ukrainian book of the XVI - XVIII centuries]. Trudy Ukrainskoho naukovoho instytutu knyhoznavstva, no. 1, pp. 1-70.

13. Novytskyi O. (1926). 'Symvolichni obrazy na rytynakh kyivskykh starodrukiv' [Symbolic images of the engravings of Kyiv's early printed books]. Notes of the Shevchenko Scientific Society, no. CXLIV, pp. 141-158.

14. Noha O. (1997). Proekt pamiatnyka Ivanu Levynskomu [The project of the monument to Ivan Levinsky]. Lviv: Ukrainski tekhnolohii.

15. Paliienko M. (2005). «Kievskaia staryna» (1882-1906). Systematychnyi pokazhchyk zmistu zhurnalu ["Kiev olden times" (1882-1906). A systematic index of the contents of the journal]. Kyiv: Tempora.

16. Paliienko M. (2005). «Kievskaia staryna» (1882-1906). Khronolohichnyi pokazhchyk zmistu zhurnalu ["Kiev olden times" (1882-1906). Chronological index of the contents of the journal]. Kyiv: Tempora.

17. Paliienko M. (2005). «Kievskaia staryna» u hromadskomu ta naukovomu zhytti Ukrainy (Kinets XIX - pochatok XX st.). ["Kiev olden times" in the public and scientific life of Ukraine (the end of XIX and early XX ct).]. Kyiv: Tempora.

18. Petrov, N. (1914). Yuzhno-russkie graviroval'nye doski tipografii Kievo-Pecherskoi, Il'inskoi, Chernigovskoi i Pochaevskoi [South Russian engraving boards of printing houses of Kiev-Pechersk, Ilinskaya, Chernihiv and Pochaev]. History of Russian Art, no.3-4, pp. 89-96.

19. Pobozhii, S. (2005). Z istorii ukrainskoho mystetstvoznavstva [From the history of Ukrainian art studies]. Sumy: VTD «Universytetska knyha».

20. Redin, E. (1905). Materialy $k$ izucheniyu tserkovnykh drevnostei Ukrainy: Tserkvi goroda Khar'kova [Materials to the study of church antiquities of Ukraine: Churches of the city of Kharkov]. Khar'kov: «Pechatnoe delo» kn. K. Gagarina

21. Titov, F. (1924). Materialy do istorii knyzhkovoi spravy na Ukraini v XVI - XVIII vv. [Materials to the history of book publishing in Ukraine in the XVI-XVIII centuries]. Kyiv: Z drukarni Ukrainskoi akademii nauk.

22. Ulianovskyi V. (1995). Vadym Shcherbakivskyi: zhyttia, naukova diialnist, dolia tvorchoi spadshchyny [Vadim Shcherbakivsky: life, scientific activity, the destiny of the creative heritage]. Kyiv: Lybid.

23. Khanko V. (2007). Mystetstvoznavcha dumka na Poltavshchyni [Art studies thought in the Poltava region]. Poltava: Poltava.

24. Shirotskii K. (1914). Ocherki po istorii dekorativnogo iskusstva Ukrainy. I. Khudozhestvennoe ubranstvo ukrainskogo doma [Essays on the history of Ukraine decorative art. I. Artistic decoration of the Ukrainian house]. Kyiv: Typohrafiia. S. Kulzhenko.

25. Shyrotskyi K. (1918). 'Tserkovni starodruky' [Early Church Books]. Bookseller.Chronicle of Ukrainian Writing, part,14, pp. 809-814.

26. Shudria, Ye. (2008). Doslidnyky ukrainskoho mystetstva. Biobibliohrafichni narysy [Researchers of Ukrainian Art. Bibliographic essays]. Kyiv: Visnyk «ANT».

(C) Удpic I. M., 2018

(C) Удріс-Бородавко Н. С,. 2018

Стаття надійшла до редакиіï: 13.10.2018 